\title{
PARTICLE SIZE DEPENDENCE OF TiO ELECTRODES IN RECHARGEABLE LITHIUM BATTERY
}

\author{
S.Y. HUANG \\ National Renewable Energy Laboratory, 1617 Cole Bld, Golden, CO80401-3393, USA \\ G. CAMPET, N. TREUIL AND J. PORTER \\ Institut de Chimie de la Matière Condensée de Bordeaux, CNRS, Université Bordeaux I, Château \\ Brivazac, Ave du Dr. A. Schweitzer, 33600 Pessac, France

\section{K. CHHOR} \\ Laboratoire d'Ingéniére des Matériaux et des Hautes Pressions, CNRS, Institut Galilée, Université Paris \\ Nord, Avenue J.B. Clément, F93430 Villetaneuse, France \\ (Received October 5, 1995; in final form January 25, 1996) \\ Particle size effects in five anatase $\mathrm{TiO}_{2}$ pellet electrodes with different particle sizes $(4 \sim 300 \mathrm{~nm})$ and \\ surface areas $\left(8 \sim 380 \mathrm{~m}^{2} / \mathrm{g}\right)$ were studied by XRD analysis, chronopotentiometry and chronoamper- \\ ometry in $\mathrm{Li} / \mathrm{LiN}\left(\mathrm{CF}_{3} \mathrm{SO}_{2}\right)_{2}+\mathrm{EC}: \mathrm{DME} / \mathrm{TiO}_{2}$ cells. Nanosized $\mathrm{TiO}_{2}$ electrodes showed by $22 \%$ larger \\ storage capacity, $50 \%$ lower overvoltage loss at the same current density, and $75 \%$ higher charge density \\ for a given time than microsized ones; electric storage capacity enhances more rapidly with decreasing \\ particle size and increasing surface area in a nanoscale region than in a microscale region. The particle \\ size dependence may be explained by surface morphology of electrodes and existence of structural \\ defects or distortion in the surface layer of $\mathrm{TiO}_{2}$ nanosized particles.
}

\section{INTRODUCTION}

$\mathrm{TiO}_{2}$ was used as a cathode active material for lithium nonaquous cells for the first time by Ohzuku et al. in $1979^{1}$. Since then, more researchers have paid attention to lithium insertion into $\mathrm{TiO}_{2}$ for the applications of electrochromic devices ${ }^{2-8}$ and lithium batteries ${ }^{9-17}$. Titanium dioxide has three common polymorphs: rutile, brookite, and anatase. They offer structurally non-equivalent host lattices for insertion of lithium ions in $\mathrm{Li}_{\mathbf{x}} \mathrm{TiO}_{2}$. In all three oxides, titanium is octahedrally coordinated to oxygen, leaving unoccupied sites available for $\mathrm{Li}$ insertion. Due to the unique primitive tetragonal packing (PTP) of $\mathrm{TiO}_{2}$-rutile, the empty channels are very narrow and limited in only one direction along axis $\mathrm{c}$; the cation radius of the empty octahedral sites is $0.40 \AA$ while the radius of a $\mathrm{Li}$ ion varies with coordination but it is normally $0.68 \AA$. At room temperature, only small amount of lithium $(x=0.15)^{13}$ can be inserted into $\mathrm{TiO}_{2}$-rutile. The packing of $\mathrm{TiO}_{2}$-brookite can be regarded as a cubic close-packing (CCP) of oxygen atoms; the free radius of the channels is approximately $0.58 \AA$, and the diffusion path for $\mathrm{Li}$ insertion is unidirectional. $\mathrm{TiO}_{2}$-brookite reacts with a small amount of lithium ${ }^{18}$. $\mathrm{TiO}_{2}$-anatase is CCP and the packing is not as dense $\left(3.84 \mathrm{~g} / \mathrm{cm}^{3}\right)$ as brookite $\left(4.17 \mathrm{~g} / \mathrm{cm}^{3}\right)$ and 
rutile $\left(4.26 \mathrm{~g} / \mathrm{cm}^{3}\right)^{19}$; the empty channels are bidirectional along axes a and $\mathrm{b}$. The maximum electrochemical $\mathrm{Li}$ insertion ratio in $\mathrm{TiO}_{2}$-anatase was reported to be $0.5-0.8^{1,9,13,15,16}$. Hence, at room temperature $\mathrm{TiO}_{2}$-anatase cathodes exhibit higher charge storage capacity compared with $\mathrm{TiO}_{2}$-rutile electrodes.

Therefore, $\mathrm{TiO}_{2}$-anatase has been of considerable interest to rechargeable lithium batteries. The $\mathrm{Li} / \mathrm{TiO}_{2}$-anatase cells present a stable working voltage plateau of about $1.78 \mathrm{~V}^{1,13,16}$. The theoretical mass and volume capacities of titanium dioxide electrode are $336 \mathrm{Ah} / \mathrm{kg}$ and $1307 \mathrm{Ah} / 1$, respectively and theoretical energy density is $598 \mathrm{Wh} / \mathrm{kg}$, based on the stoichiometry of $\mathrm{LiTiO}_{2}$. These performances are better than that of most other transition metal oxide or sulphide electrode materials such as $\mathrm{TiS}_{2}(239 \mathrm{Ah} / \mathrm{kg})$ and $\mathrm{MoO}_{3}(320 \mathrm{Ah} / \mathrm{kg})$ etc; supporting $\mathrm{x}=1$.

$\mathrm{TiO}_{2}$-anatase is a promising electrode material for primary or secondary lithium battery application. However, in the previous studies there were no reports on particle size effects in $\mathrm{TiO}_{2}$ electrode materials. Recent investigations of nanocrystalline $\mathrm{TiO}_{2}$ films ${ }^{15,16}$ and powders ${ }^{20}$ show that the performance of a lithium battery, i.e., its reversible capacity, cycle life, and electric energy storage efficiency, not only depend on the host lattice structure but also on the morphology of the electrodes, which is related to particle size and surface area. These nanocrystlline $\mathrm{TiO}_{2}$ electrodes consist of nanosized particles and are distinguished by a very high internal surface area. Pores, open channels, and borders of grains are present between the oxide particles; these become filled with electrolyte solution. In this situation, the diffusion of lithium ions from an electrolyte solution into solid electrodes is much easier and the lithium insertion process can occur reversibly into a surface layer of small oxide particles, i.e., lithium insertion/desinsertion is more efficient. In this paper, we study several kinds of $\mathrm{TiO}_{2}$-anatase pellets made by pressing the starting powders with different particle size, from 4 to $300 \mathrm{~nm}$, and different surface area, from 8 to $380 \mathrm{~m}^{2} / \mathrm{g}$. The correlations between $\mathrm{TiO}_{2}$ electrode performances (charge storage capacity, lithium insertion ratio, and cycle life) with particle size and surface area of starting materials are discussed.

\section{EXPERIMENTAL}

The commercial powders from Fluka, commercial powders Hombikat UV100, industrial testing powders IF9425/8, IF9425/11 from Sachtleben Chemie GmbH, and testing powders PKP09040 from Bayer were chosen as starting materials. The cathode mix consisted of $88 \mathrm{wt} \% \mathrm{TiO}_{2}$ powders, $10 \mathrm{wt} \%$ graphite (Lonza KS-10) and $2 \mathrm{wt} \%$ polyvinylidenedifluoride binder (Solway Solef 6010/1001) dissolved in dimethylformamide solution. Total mass of the mixture was $40 \mathrm{mg}$. The starting powders were well-mixed and then pressed into pellets with a diameter of $6.2 \mathrm{~mm}$ and thickness of ca. $0.65 \mathrm{~mm}$. The pressing pellets were dried at $180^{\circ} \mathrm{C}$ for $48 \mathrm{~h}$ under $10^{-2}$ torr. The dried pellets were placed in a glove box to avoid any air contact.

The BET surface area measurements ( $\mathrm{Kr}$ isotherms, Accusorb 2100E, Micromeritics) were carried out by using nitrogen gas for the pressing pellets.

The electrolyte solution was $1 \mathrm{M} \mathrm{LiN}\left(\mathrm{CF}_{3} \mathrm{SO}_{2}\right)_{2}$ dissolved in ethylene carbonate (EC):1,2-dimethoxyethane (DME) (1:1 by mass). $\mathrm{LiN}\left(\mathrm{CF}_{3} \mathrm{SO}_{2}\right)_{2}(3 \mathrm{M}$, Fluorad 
HQ-115) was dried at $130^{\circ} \mathrm{C}$ under $10^{-2}$ torr for $48 \mathrm{~h}$. The solvent mixture EC:DME was dried over a $4 \AA$ molecular sieve. The prepared electrolyte solution was kept in a bottle with alumina particles as drying agent, water content in the solution was $11 \mathrm{ppm}$, as determined by Karl-Fisher titration.

A Teflon tube was used as a body of the cell and two stainless-steel spigots were employed as electric contacts of this two-electrode system. A disk of lithium metal used as the anode and $\mathrm{a} \mathrm{TiO}_{2}$ mix pellet used as the cathode were placed against the the stainless-steel spigots. A two-polyporous film consisting of a microporous polypropylene nonwoven cloth (Celguard 2400) was used as a separator. All procedures in handling the cells and electrochemical cycling tests were performed in an argon-filled dry box in which the oxygen level was maintained in the region of $4 \mathrm{ppm}$ and the $\mathrm{H}_{2} \mathrm{O}$ level in the region of $10 \mathrm{ppm}$.

\section{RESULTS AND DISCUSSION}

Figure 1 shows the correlation between surface area $S$ and particle size $D$ of $\mathrm{TiO}_{2}$-anatase starting powders; the circles represent the data offered from manufactures and the line is theoretical results calculated by using the following equation:

$\mathrm{S}=\frac{6 \times 10^{3}}{\mathrm{D} \rho}$

where $\rho$ is the density of $\mathrm{TiO}_{2}$-anantase, $\mathrm{S}$ in $\mathrm{m}^{2} / \mathrm{g}, \mathrm{D}$ in $\mathrm{nm}$ and assuming spherical particles. Surface area, as a function of particle size, increases more quickly in the nanoscale region than in the microscale region. The surface area and primary particle size of starting powders are listed in Table I. The BET measurements show that the decrease of surface area in the pressed pellets is less than $5 \%$ by comparison with that in starting powders.

Chronopotentiostatic cycling of $\mathrm{Li} / \mathrm{LiN}\left(\mathrm{CF}_{3} \mathrm{SO}_{2}\right)_{2}, \mathrm{EC}: \mathrm{DME} / \mathrm{TiO}_{2}$ cells was carried out by using different current densites: $0.33,0.66,0.99 \mathrm{~mA} / \mathrm{cm}^{2}$ and $1.32 \mathrm{~mA} /$

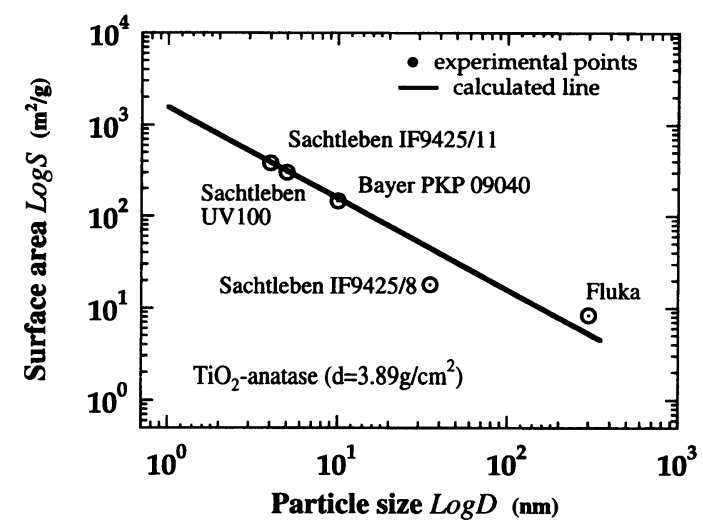

FIGURE 1 Correlation between surface area $\mathrm{S}$ and particle size $\mathrm{D}$ of $\mathrm{TiO}_{2}$-anatase starting materials. 
TABLE I

Characterization of $\mathrm{TiO}_{2}$ starting powders and testing results of their pellet electrodes

\begin{tabular}{lcccc}
\hline Commercial name & $\mathrm{D}(\mathrm{nm})$ & $\mathrm{S}\left(\mathrm{m}^{2} / \mathrm{g}\right)$ & Capacity* $(\mathrm{mAh} / \mathrm{g})$ & $\mathrm{I}_{\text {r.s. }}(\mathrm{mA} / \mathrm{cm} 2)$ \\
\hline Fluka & $\sim 300$ & 8 & 144 & $7.5 \times 10^{-5}$ \\
Sachtleben IF9425/8 & 35 & 18 & 151 & $3.1 \times 10^{-5}$ \\
Bayer PKP 09040 & 10 & 145 & 154 & $3.9 \times 10^{-6}$ \\
Sachtleben UV100 & 5 & 300 & 171 & $1.9 \times 10^{-6}$ \\
Sachtleben IF9425/11 & 4 & 380 & 178 & $1.5 \times 10^{-6}$ \\
\hline
\end{tabular}

*measured at a constant current density of $0.66 \mathrm{~mA} / \mathrm{cm}^{2}$.

$\mathrm{cm}^{2}$. The discharge and charge curves of the cells measured at a constant current density of $0.66 \mathrm{~mA} / \mathrm{cm}^{2}$ are given in Fig 2 and the overvoltage loss is shown in the inset figure. The freshly assembled cells had initial open circuit voltages of $\sim 3 \mathrm{~V}$. The final voltage during discharge was $1.5 \mathrm{~V}$ : smaller voltages were avoided to prevent cathodic decomposition of the electrolyte solution. The discharge/charge behaviors are quite different between the particular $\mathrm{TiO}_{2}$ electrodes: (i) electrochemical insertion ratio of lithium ions increases while particle size decreases in these five samples. During discharge, $\mathrm{x}$ was found to be $0.43,0.45,0.46$, 0.51, and 0.53 for Fluka, IF9425/8, Bayer, UV100, and IF9425/11, respectively. From the ratio of the discharge and charge capacity, one derives a reversibility of $\sim 95 \%$; (ii) the overvoltage losses $\Delta \mathrm{V}$, calculated by the difference of charging and discharging potentials at $\frac{1}{2} \mathrm{x}_{\max }$, are $\sim 0.31 \mathrm{~V}$ for the Fluka sample and $0.29 \mathrm{~V}$ for IF $9425 / 8$ sample at a current density of $0.66 \mathrm{~mA} / \mathrm{cm}^{2}:$ in the case of the nanoscale active materials, the overvoltage loss is much smaller, the average value is $\sim 0.15 \mathrm{~V}$.

The variation of the storage capacity of $\mathrm{TiO}_{2}$ electrodes with current density is plotted in Fig. 3. The results of three representative electrodes of $\mathrm{TiO}_{2}$ Fluka, Bayer, and IF9425/11 are shown. The storage capacity increases with decreasing current density for all three samples. The highest storage capacity was obtained by

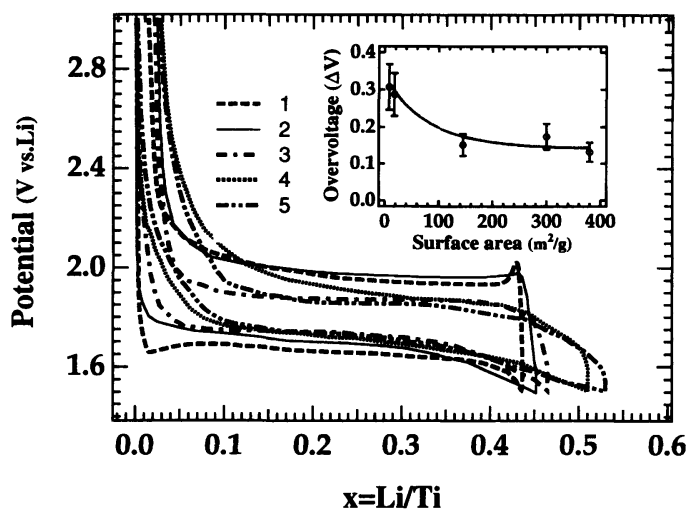

FIGURE 2 Chronopotentiostatic discharge/charge curves of the $\mathrm{Li} / \mathrm{LiN}\left(\mathrm{CF}_{3} \mathrm{SO}_{2}\right)_{2}, \mathrm{EC}: \mathrm{DME} / \mathrm{TiO}$ cells using different anatase samples: 1-Fluka, 2-Sachtleben IF9425/8, 3-Bayer PKP09040, 4-UV100, 5 -Sachtleben IF9425/11; current density was $0.66 \mathrm{~mA} / \mathrm{cm}^{2}$. Inset: Overvoltage loss, calculated by using the potential difference between charge and discharge plateaus at $1 / 2 \mathrm{x}_{\max }$, as function of surface area of each sample from \#1 to \#5. 


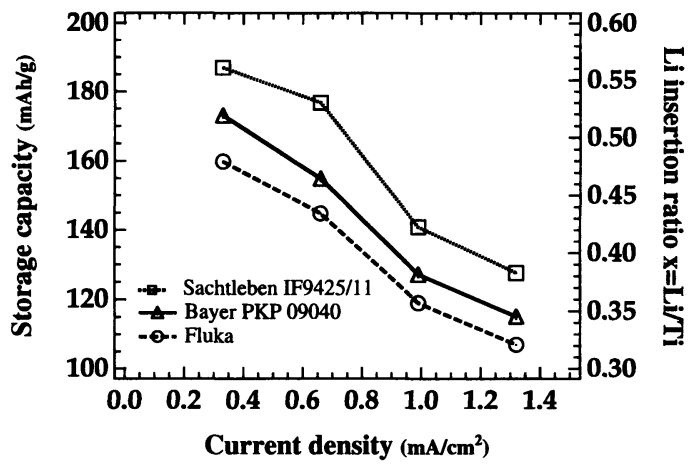

FIGURE 3 Variation of the storage capacity and lithium insertion ratio of $\mathrm{Li} / \mathrm{LiN}\left(\mathrm{CF}_{3} \mathrm{SO}_{2}\right)_{2}$, EC:DME $/ \mathrm{TiO}_{2}$ cells with current density for different anatase materials.

using a current density of $0.33 \mathrm{~mA} / \mathrm{cm}^{2} ; 182,174$, and $155 \mathrm{mAh} / \mathrm{g}$ corresponding to a lithium insertion ratio of $\mathrm{x}=0.55,0.52$, and 0.47 for $\mathrm{TiO}_{2}$ IF9425/11, Bayer, and Fluka, respectively.

The charge density of $\mathrm{TiO}_{2}$ pellet electrodes, as a function of time, is plotted in Fig. 4 for both discharging and charging processes. For a given time, $\mathrm{TiO}_{2}$ electrodes with nanosized particles deliver and obtain much more charge during discharging and charging process, respectively, than that with microsized particles.

Fig. 5 shows the reversibility of storage capacity of the $\mathrm{Li} / \mathrm{LiN}\left(\mathrm{CF}_{3} \mathrm{SO}_{2}\right)_{2}$, EC:DME/TiO 2 with nanosized powders (Bayer and IF9425/11) and microsized powder (Fluka). The electrochemical cyclings were carried out at a relatively higher current density of $1.32 \mathrm{~mA} / \mathrm{cm}^{2}$ in order to make cycle life test in a reasonable time. The nanosized materials exhibit excellent electrochemical cyclability until 80 cycles for IF9425/11 and 90 cycles for Bayer, with a drop of capacity of $\sim 22 \%$ at the last cycle. In contrast, the initial capacity of microsized electrode (Fluka) cannot be repeted at all.

The rapid and reversible insertion of lithium ions into $\mathrm{TiO}_{2}$ microcrystalline and nanocrystalline electrodes is demonstrated above. The differences of electrochemi-

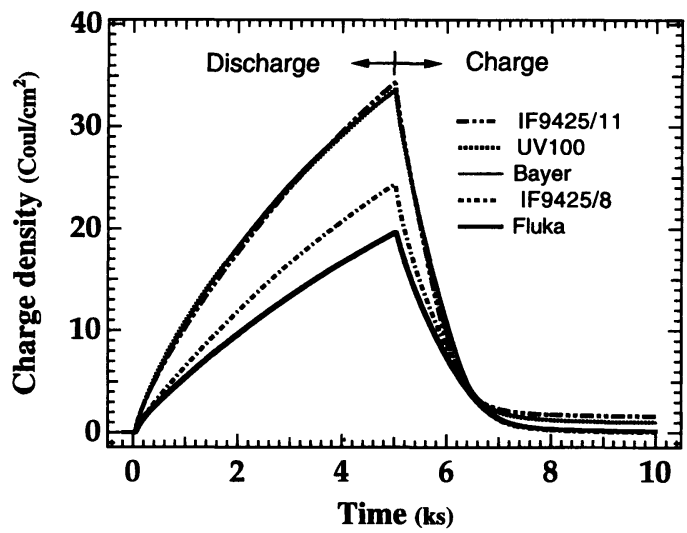

FIGURE 4 Charge density following a potential step from $3-1.5 \mathrm{~V}$ for the $\mathrm{Li} / \mathrm{LiN}\left(\mathrm{CF}_{3} \mathrm{SO}_{2}\right)_{2}$, $\mathrm{EC}: \mathrm{DME} / \mathrm{TiO}_{2}$ cells with different starting materials. 


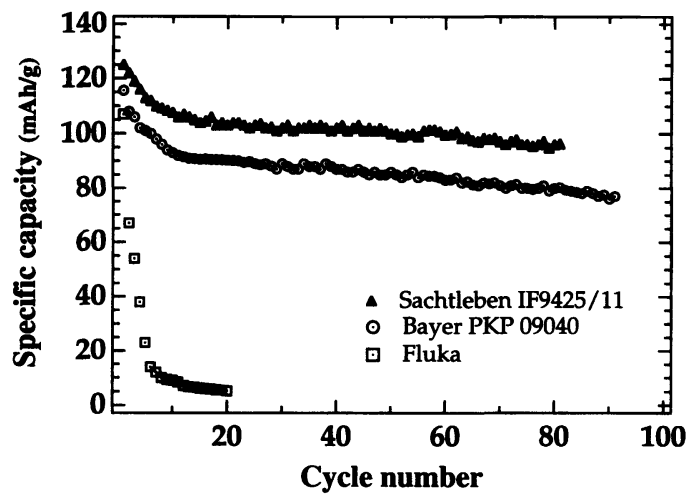

FIGURE 5 Cyclebility of storage capacity of the $\mathrm{Li} / \mathrm{LiN}\left(\mathrm{CF}_{3} \mathrm{SO}_{2}\right)_{2}, \mathrm{EC}: \mathrm{DME} / \mathrm{TiO}{ }_{2}$ cells with nanoscale powder (Bayer) and microscale powder (Fluka) at the relatively high current density of $1.32 \mathrm{~mA} / \mathrm{cm}^{2}$

cal performances between these two scale-particle-sized electrodes can be observed in the Figs. 2-5 and Table I. The electrochemical capacity of nanocrystalline electrodes is $\sim 22 \%$ higher than that of microcrystalline ones at the same current density: overvoltage loss in the nanosized particle electrodes is $\sim 50 \%$ lower than that in the microsized particle ones. Charge density in the nanocrystalline electrodes is $\mathbf{7 5 \%}$ higher than in the microcrystalline ones for the same charging/ discharging time, i.e., the electrochemical kinetics of lithium insertion/deinsertion in $\mathrm{TiO}_{2}$ structure with nanosized particles is much higher than in $\mathrm{TiO}_{2}$ with microsized particles. Fig. 6 shows the variations of storage capacity of these five $\mathrm{TiO}_{2}$ electrodes as a function of particle sizes in the starting powders. Two different slopes of the storage capacity lines can be observed in the microscale and nanoscale regions for each current density used, i.e., the storage capacity increases more rapidly in the nanoscale region than in the microscale region with decreasing particle size of $\mathrm{TiO}_{2}$ starting powders.

An interpretation of the particle size dependence observed above may be expected by analyzing lithium intercalating process into $\mathrm{TiO}_{2}$ structures and by

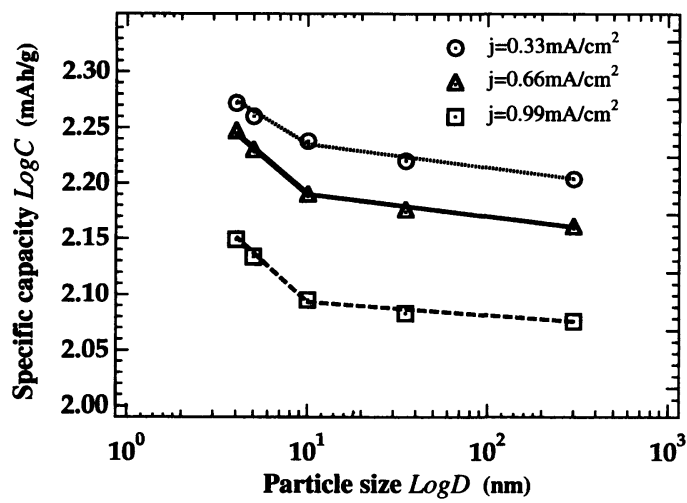

FIGURE 6 Variation of storage capacity with particle size of the $\mathrm{Li} / \mathrm{LiN}\left(\mathrm{CF}_{3} \mathrm{SO}_{2}\right)_{2}, \mathrm{EC}: \mathrm{DME} / \mathrm{TiO}{ }_{2}$ cells. 
electrochemical reaction mechanism. The structure of anatase $\mathrm{TiO}_{2}$ has the tetragonal space group $\mathrm{I}_{1} /$ amd with $\mathrm{Ti}^{4+}$ at position $(4 \mathrm{a}, 000)$ and $\mathrm{O}^{2-}$ at position $(8 \mathrm{e}, 00 \mathrm{z}, \mathrm{z}=0.2081)$ and 4 formula unit/crystallographic unit. The octahedral sites at positions $(4 \mathrm{~b}, 000)$ are vacant with respect to cations, and may accommodate cations having almost the same ionic radii as $\mathrm{Ti}^{3+}(0.67 \AA)$ and $\mathrm{Ti}^{4+}(0.61 \AA)$, ex. $\mathrm{Li}^{+}(0.68 \AA)$. On lithiation, the crystal network of anatase $\mathrm{TiO}_{2}$ extends with lithium intercalation ${ }^{12}$. The tetragonal symmetry is broken while the lithium insertion ratio $\mathrm{x}$ reaches $0.3-0.6$; the unit cell becomes orthorhombic with space group Imma ${ }^{12,14}$. Inspection of both the powder $\mathrm{X}$-ray diffraction and neutron diffraction patterns of $\mathrm{Li}_{\mathrm{x}} \mathrm{TiO}_{2}$ indicated that the unit volume of $\mathrm{Li}_{0.5} \mathrm{TiO}_{2}$ orthorhombic cell is $\sim 4 \%$ larger than that of $\mathrm{TiO}_{2}$ tetragonal cell ${ }^{12,14}$. The insertion of lithium ions into the $\mathrm{TiO}_{2}$ structure also accompanies the reduction of $\mathrm{Ti}^{4+}$. Therefore, the total reaction process in $\mathrm{a}^{\mathrm{Ti}_{4}} \mathrm{O}_{8}$ unit cell can be represented as

$$
\begin{aligned}
& \text { tetragonal } \mathrm{x}=0 \quad \text { tetragonal } \mathrm{x} \leq 0.3 \sim 0.6 \quad \text { orthorhombic } \mathrm{x} \geq 0.3 \\
& \square \mathrm{Ti}_{4}{ }^{4+} \mathrm{O}_{8}{ }^{2-}+\mathrm{xLi}^{+}+\mathrm{xe}^{-} \rightleftarrows \mathrm{Li}_{\mathrm{x}}{ }^{+} \mathrm{Ti}_{4-\mathrm{x}}{ }^{4+} \mathrm{Ti}_{\mathrm{x}}{ }^{3+} \mathrm{O}_{8}{ }^{2-} \rightleftarrows \mathrm{Li}_{\mathrm{x}}{ }^{+} \mathrm{Ti}_{4-\mathrm{x}}{ }^{4+} \mathrm{Ti}_{\mathrm{x}}{ }^{3+} \mathrm{O}_{8}{ }^{2-} \\
& \text { (4b) (4a) (8e) } \\
& \text { (xb) ((4-x)a) (4xa) (8e) } \\
& \text { (xe) }((4-x) e)(4 x e)(8 e)
\end{aligned}
$$

where $\square$ denotes vacant sites. These intercalating reactions begin in the surface layer of $\mathrm{TiO}_{2}$ particles and the lithium ions insert progressively into the pits.

Insertion of lithium ions into a $\mathrm{TiO}_{2}$ network not only accompany structural charges such as extension of unit cell volume and phase transition, but also leads to an amorphism or distortion in the surface layer structure of each $\mathrm{Li}_{\mathrm{x}} \mathrm{TiO}_{2}$ particle. Fig. 7 shows the ex-situ XRD analysis of $\mathrm{TiO}_{2}$ during lithium electrochemical insertion. The half-height width of diffraction reflections become broadened and the intensity drops upon lithium insertion. This fact indicates the surface layer of $\mathrm{TiO}_{2}$ particles becomes distorted or amorphisized because of the insertion and presence of lithium ions. The possible mechanism of this amorphization is illustrated in Fig. 8: the size of crystallite decreases upon lithium insertion. It implies that the surface packing density of the atoms in the lattice planes is not low enough to allow efficient lithium insertion. After the first insertion of lithium ions, the surface layer (shaded area in Fig. 8) of a crystallite is modified. As stated above, the diffusion of lithium ions into a $\mathrm{TiO}_{2}$ network plays an important role on $\mathrm{Li} / \mathrm{TiO}_{2}$ cell performances. It should be noted that the surface morphology of the $\mathrm{TiO}_{2}$ electrodes also controls numerous physical and chemical functions in lithium intercalation processes. This aspect is responsible for the geometric-to-real-surface ratio in comparison to the planar electrode. For example, the current density $0.66 \mathrm{~mA} / \mathrm{cm}^{2}$ of a planar electrode can be transferred as the real surface current density for each sample (the current charging on $\mathrm{TiO}_{2}$ particles): $7.1 \times 10^{-5} \mathrm{~mA} / \mathrm{cm}^{2}$ for $\mathrm{TiO}_{2}$ Fluka $\left(8 \mathrm{~m}^{2} / \mathrm{g}\right)$ and $1.5 \times 10^{-6} \mathrm{~mA} / \mathrm{cm}^{2}$ for $\mathrm{TiO}_{2}$ Sachtleben IF9425/11 $\left(380 \mathrm{~m}^{2} / \mathrm{g}\right)$, i.e., the current density on the real surface in the electrode of Fluka is 47 times higher than that in the electrode of IF9425/11. That is why overvoltage loss in the Fluka electrode is much higher in the IF9425/11 one. A maximum possible area of interface between electrode and electrolyte gives rise to the high rates of 


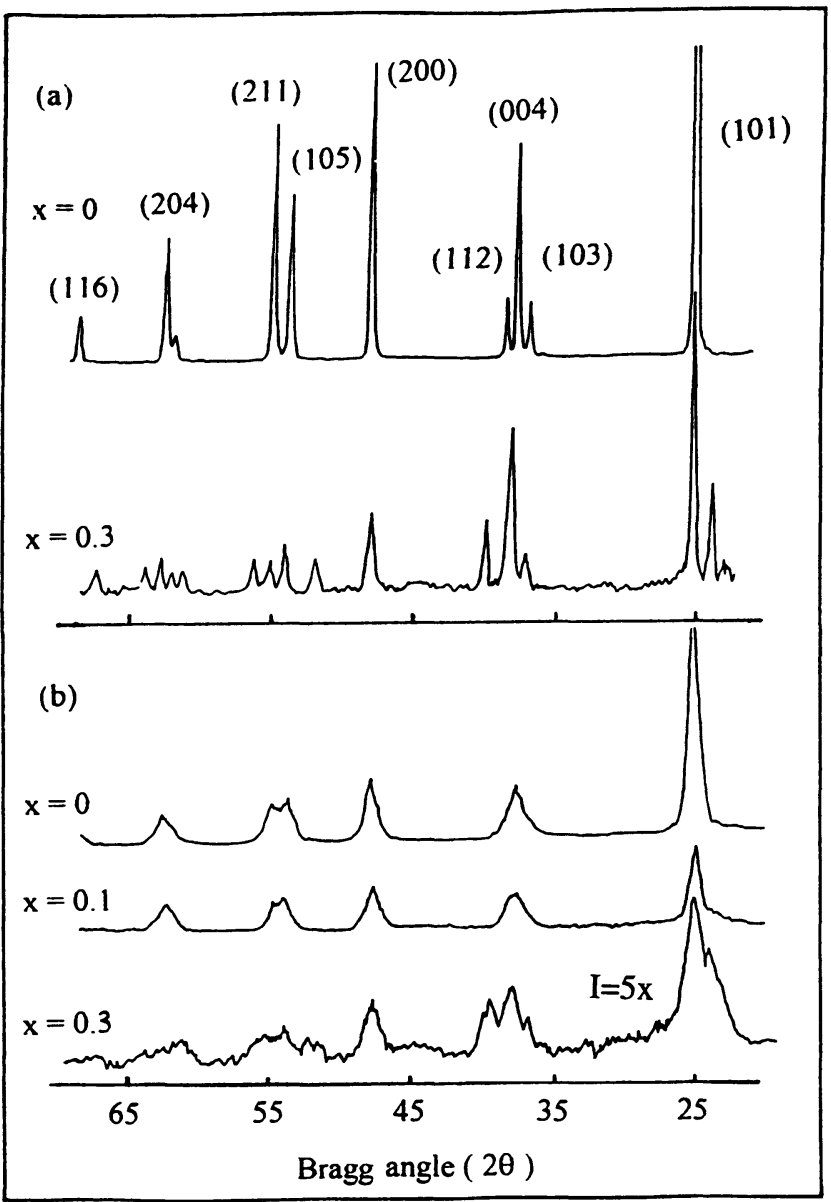

FIGURE 7 X-ray diffraction of $\mathrm{Li}_{\mathbf{x}} \mathrm{TiO}_{2}$ powders (a): $\mathrm{TiO} 2$ with lager particle size (Fluka), (b): with smaller particle size (UV100).

reactions. That may be the reason for higher electrochemical kinetics in nanosized particle electrodes than in microsized particle ones: larger storage capacity and higher charge density during charge/discharge processes.

In fact, by minimizing the $\mathrm{TiO}_{2}$ particle size we not only decrease the $\mathrm{Li}^{+}$ diffusion time, but also favor the formation of defect bonds or distorted structures at the surface layer, such as anions adjacent to cation vacancies. These structural defects may act as reversible insertion/desinsertion sites for lithium ions. The formation of structural defects at the surface layer of $\mathrm{TiO}_{2}$ particles is more obvious in the nanoscale region than in the microscale region. Indeed, the concentration of subband-gap energy states, arising from the structural defects at the surface layer of $\mathrm{TiO}_{2}$ particles, increases at the crystallite size is reduced. This causes, for low insertion ratios $\mathrm{x}$, a pushing of the Fermi energy, i.e., higher electron affinity, and thereby of the open-circuit voltage $V_{o c}$ towards anodic values: the $V_{o c}$ are indeed larger for the electrodes having the smaller particle size (Fig. 9). 


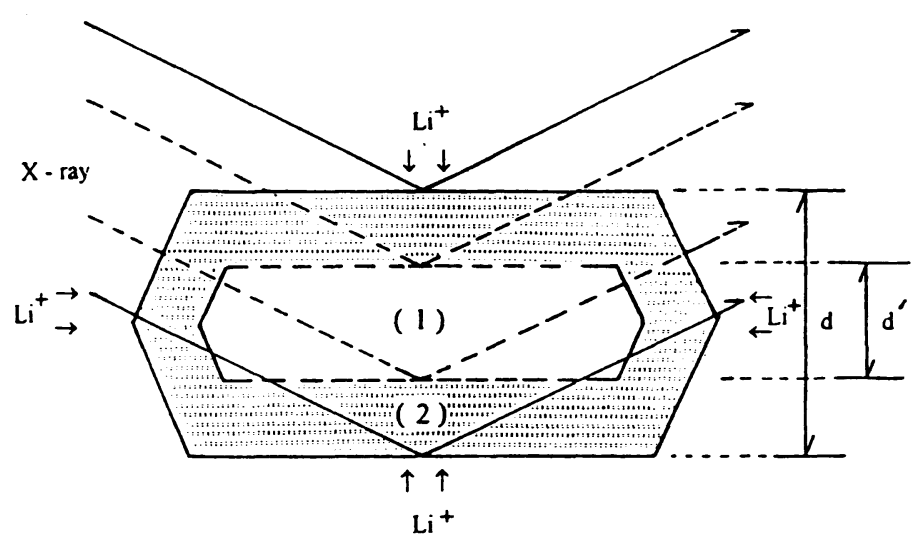

FIGURE 8 Decrease of the size of crystallite upon lithium insertion: (1) well crystallized remaining region of composition $\mathrm{Li}_{\mathbf{x}} \mathrm{TiO}_{2} ;(2)$ amorphous region of composition $\mathrm{Li}_{\mathbf{x}}{ }^{\prime} \mathrm{TiO}_{2}\left(\mathrm{x}^{\prime}>\mathrm{x}\right)$, formed during lithium insertion. $d-d^{\prime}=\Delta d_{h k l}$ illustrates the enlargement of the X-ray diffraction peaks due to the lithium insertion.

\section{CONCLUSIONS}

A series of anatase $\mathrm{TiO}_{2}$ electrodes with different particle sizes and surface areas has been used in the $\mathrm{Li} / \mathrm{LiN}\left(\mathrm{CF}_{3} \mathrm{SO}_{2}\right)_{2}, \mathrm{EC}: \mathrm{DME} / \mathrm{TiO}_{2}$ cells and their electrochemical properties have been investigated. A particle size effect in the $\mathrm{TiO}_{2}$-anatase electrodes of rechargeable lithium batteries was observed: the storage capacity and electrochemical kinetic of the cells increase as the particle sizes of starting powders decrease and the surfaces area rise. Unlike the surface area $S$ scale $1 / D$, the correlation between storage capacity of $\mathrm{TiO}_{2}$ electrodes and particle sizes or surface areas of starting materials were different in the nanoscale and microscale regions. The nanosized electrodes always exhibit higher capacity and reversibility than microsized electrodes. This particle size dependence of $\mathrm{TiO}_{2}$ electrode performance may be explained by surface morphology (geometric-to-real-surface ratio) of electrodes and existence of structural defects or distortion at the surface layer of $\mathrm{TiO}_{2}$ particles when their size decreases into the nanoscale region.

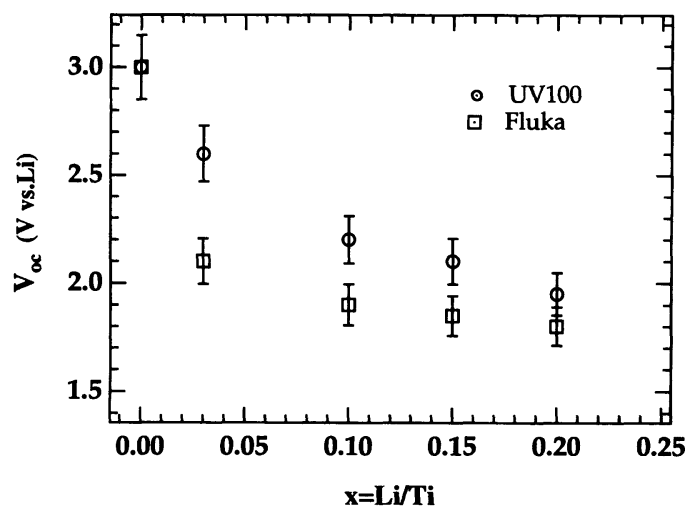

FIGURE 9 Equilibrium open circuit voltages $\mathrm{V}_{\text {oc }}$ versus insertion ratio $\mathrm{x}$ for two $\mathrm{Li} / \mathrm{Li}^{+} / \mathrm{TiO}_{2}$ cells during discharging process. 


\section{ACKNOWLEDGEMENTS}

G. Campet, N. Treuil and J. Portier wish to thank the "CNET (Centre National ol ' Etuole oles Télécommunications)-92 Issy les Moulineausc - France" for its helpful assistance and financial support.

\section{REFERENCES}

1. T. Ohzuku, Z. Takehara and S. Yoshizawa, Electrochimica Acta., 24, 219 (1979).

2. H. Kuster and J. Ebeert, Thin Solid Films, 70, 43 (1980).

3. T. Ohzuku and T. Hirai, Electrochimica Acta 27, 1263 (1982).

4. F. H. Moser and N. R. Lynam, US Patent 4,855,161 (1989).

5. N. Ozer, D. G. Chen and J. H. Simmons, Ceram. Trans., 20, 253 (1991).

6. N. Ozer, Thin Solid Films, 214, 17 (1992).

7. N. Ozer, F. Tepehan and N. Bozkurt, Thin Solid Films, 219, 193 (1992)

8. A. Hagfeldt, N. Vlachopoulos and M. Grätzel, J. Electrochem. Soc., 141, L82 (1994).

9. F. Bonino, L. Busani, M. Lazzari, M. Manstretta, B. Rivolta and B. Scrosatti, J. Power Sources, 6, $261(1981)$

10. D. Bi. J. Wang, Y. Sun and Z. Liao, Proc. Electrochem. Soc., 80-7, 245 (1980).

11. M. Voinov, Proc. Electrochem. Soc., 81-4, 352 (1981).

12. T. Ohzuku and T. Kodama, J. Power Sources, 14, 153 (1985).

13. B. Zachau-Christiansen, K. West, T. Jacobsen and S. Atlung, Solid State Ionics, 28-30, 1176 (1988).

14. R. J. Cava, D. W. Murphy, S. Zahurak, A. Santoro and R. S. Roth, J. Solid State Chem., 53, 64 (1984).

15. B. Zachau-Christiansen, K. West, T. Jacobsen and S. Atlung, Solid State Ionics, 53-56, 364 (1992).

16. S. Y. Huang, L. Kavan, M. Grätzel and I. Exnar, Active and Passive Electronic Components, 18, 23 (1995).

17. L. Kavan, K. Kratochvilova and M. Grätzel, J. Electroanal. Chem. in press.

18. D. W. Murphy, R. J. Cava, S. M. Zahurak and A. Santoro, Solid State Ionics 9-10, 413 (1983).

19. CRC Handbook of Chemistry and Physics, 69th edition, Ed. Robert C. Weast, CRC Press, Inc. Florida, 1987.

20. S. D. Han, N. Treuil, G. Campet, J. Portier, C. Delmas, J. C. Lassegues and A. Pierre, Materials Science and Engineering, B18, 201-208 (1993). 

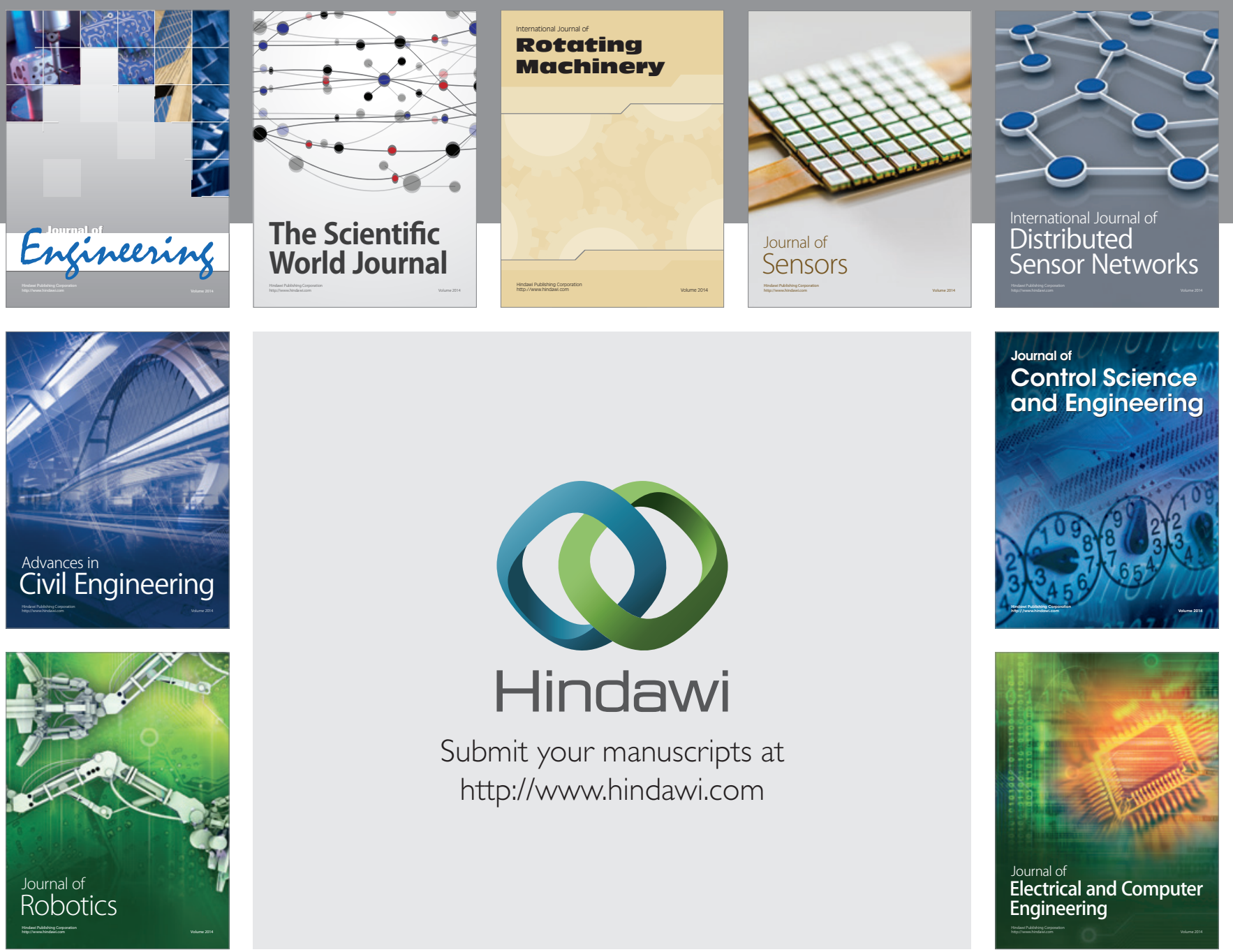

Submit your manuscripts at

http://www.hindawi.com
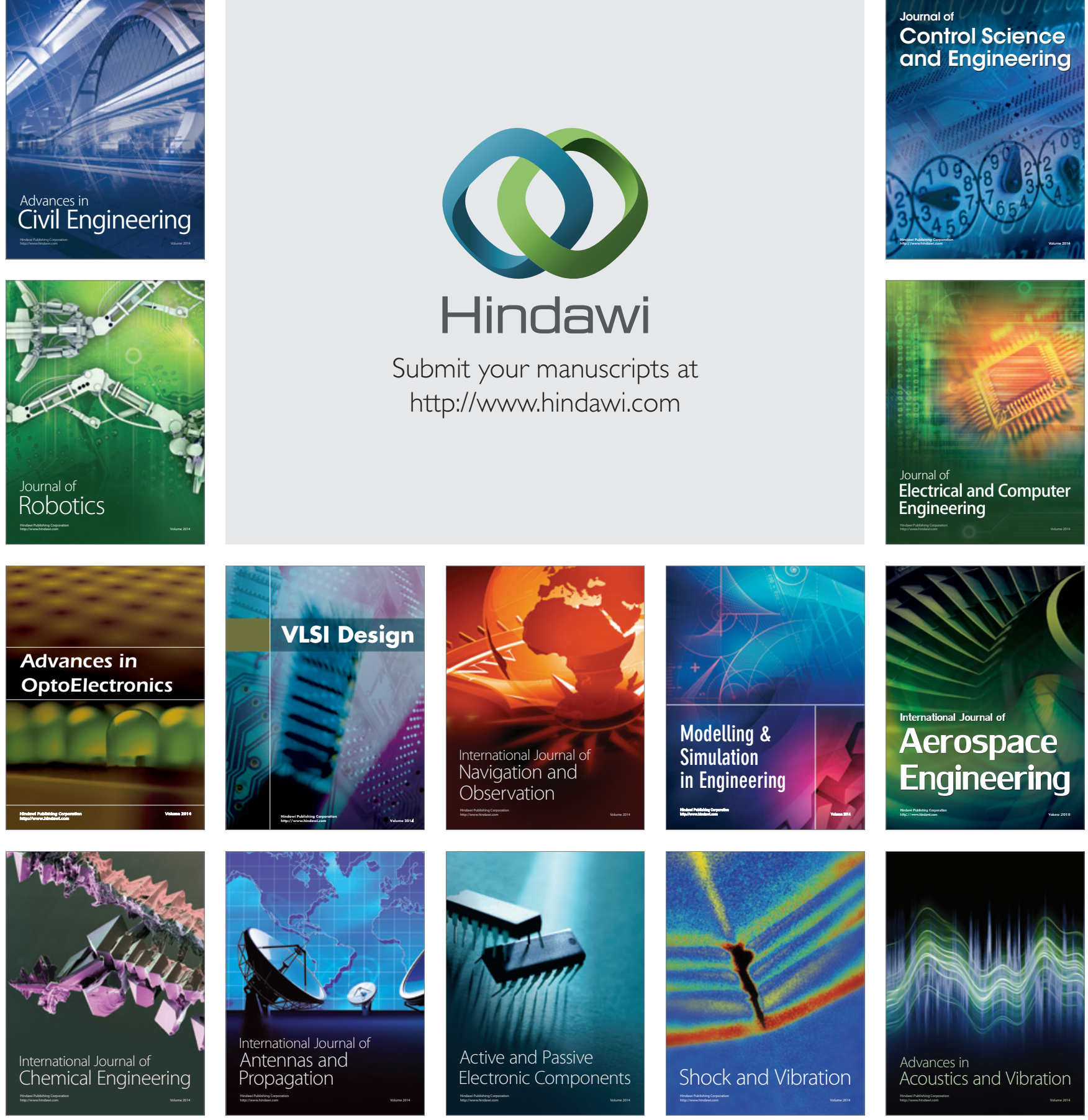